\title{
THE EFFECT OF COLLAGENASE-LIKE PEPTIDASE FROM RAT TESTIS AND CLOSTRIDIAL COLLAGENASE A ON THE RAT SEMINAL VESICLE SECRETION AND ITS COAGULATION
}

\author{
E. KOREN, J. LUKAC̆ AND S. MILKOVIĆ \\ Laboratory for Experimental Medicine, University of Zagreb, Vinogradska c. 29, \\ 41000 Zagreb, Kugoslavia
}

(Received 30th Fanuary 1973)

Summary. Collagenase-like peptidase (CLP), an enzyme recently
discovered in human, rat and bull spermatozoa and rat and bull testes,
was purified from the rat testis homogenate by acetone precipitation
and gel filtration on Sephadex G-200. This enzyme is inhibited by
cysteine and EDTA, but not by DFP and Trasylol, and does not show
measurable non-specific proteolytic or amidase activity.
Using disc electrophoresis on polyacrylamide gels, it was demonstrated
that purified CLP from rat testis and clostridial collagenase A degraded
the basic proteins, and to a lesser extent some of the neutral and acid
proteins from the rat seminal vesicle secretion. A certain similarity
was observed in their basic protein degradation products. It was
ascertained by macroscopical examination that CLP and clostridial
collagenase A prevent, by their lytic action, coagulation of the vesicular
secretion. This applies both to spontaneous and vesiculase-mediated
coagulation.
The specificity of collagenases and the rôle of CLP are discussed.

\section{INTRODUGTION}

There is evidence that the coagulation of the ejaculated semen of the rat (Mann, 1954; Manyai, 1964; Manyai, Beney \& Czuppon, 1965) and guineapig (Gotterer, Ginsberg, Schulman, Banks \& Williams-Ashman, 1955) is due to interaction of the basic proteins of the seminal vesicle secretion with vesiculase, an enzyme in the coagulating gland, and perhaps with Cowper's gland secretion (Hart, 1968, 1969, 1970).

In our previous report on the presence of collagenase-like peptidase (CLP) in human, rat and bull spermatozoa and in rat and bull testes (Koren \& Milković, 1973), we suggested that this enzyme might participate, by its lytic action, in the promotion of sperm motility through the female genital tract.

This report presents evidence showing that CLP from rat testis and clostridial collagenase $A$ have certain effects on the proteins of the rat seminal vesicle secretion and on their coagulation. 


\section{MATERIALS AND METHODS}

Synthetic PZ-pentapeptide or collagenase chromophor substrate (4-phenylazobenzyloxy-carbonyl-L-prolyl-L-leucyl-L-glycyl-L-prolyl-D-arginin) was obtained from Fluka, Switzerland, ethylenediaminetetra-acetic disodium salt (EDTA), di-iso-propyl fluorophosphate (DFP) and N-L-benzoyl-DL-arginin-p-nitroanilide hydrochloride (BAPA) from B.D.H., Great Britain and cysteine from Merck, Germany. Each chemical was of analytical grade. Alpha-casein, haemoglobin, bovine serum albumin and purified clostridial collagenase A were purchased from the Worthington Biochemical Corporation, USA. Trypsin-kallikrein inhibitor (Trasylol) was obtained from Bayer, Germany.

In all experiments, sexually mature Fischer-strain male rats aged 6 to 8 months and weighing 260 to $300 \mathrm{~g}$ were used.

\section{Purification methods}

The ammonium sulphate precipitation method (Koren \& Milković, 1973) was replaced by precipitation with acetone, as the latter was found to yield more purified CLP. Portions $(10 \mathrm{~g})$ of testis tissue were homogenized in an Ultra-Turax homogenizer at $4^{\circ} \mathrm{C}$, diluted up to $50 \mathrm{ml}$ with $0.05 \mathrm{M}$-tris-acetate buffer, $\mathrm{pH} 7 \cdot 5$, containing $0.05 \mathrm{M}-\mathrm{NaCl}$, and then centrifuged at $12,000 \mathrm{~g}$ for 20 min at $4^{\circ} \mathrm{C}$. The supernatant was gradually saturated by slow addition of acetone at $0^{\circ} \mathrm{C}$. Magnetic stirring was constantly provided. The precipitates were removed by centrifugation $\left(12,000 \mathrm{~g}, 20 \mathrm{~min}, 0^{\circ} \mathrm{C}\right)$ after $20,43,50,55$, 59 and $69 \% \mathrm{v} / \mathrm{v}$ acetone saturation had been reached. Each precipitate was dissolved in $15 \mathrm{ml}$ of the same buffer. After determination of the CLP activity and protein concentration, the 50 to $55 \%$ and 55 to $59 \%$ fractions which showed the highest activities were pooled and passed through Sephadex G-200 column $(45 \times 2.5 \mathrm{~cm})$, equilibrated and eluted with the same tris-acetate buffer at a flow rate of $12 \mathrm{ml} / \mathrm{hr}$. Fractions $(5 \mathrm{ml})$ were collected. One CLP activity peak was obtained in the eluate. The CLP elution volume was comparable to that obtained previously (Koren \& Milković, 1973). The contents of two adjacent tubes showing the highest CLP activity were pooled and used in all experiments.

Vesiculase was purified from rat prostate and tested by the method of Gotterer et al. (1955).

Seminal vesicle secretions were taken from animals under ether anaesthesia by puncturing the seminal vesicle with a large needle and sucking the contents into a dry syringe. Up to $0.3 \mathrm{ml}$ greenish-yellow turbid viscous fluid could be obtained. Certain amounts of insoluble material were always present.

The effects of CLP, clostridial collagenase and vesiculase on the proteins of seminal vesicle secretions were examined macroscopically and by disc electrophoresis.

\section{Coagulation of the seminal vesicle secretion}

Spontaneous coagulation of the seminal vesicle secretion was studied in small Petri dishes $(4.5 \mathrm{~cm}$ in diameter). Portions $(0.2 \mathrm{ml})$ of seminal vesicle secretion were mixed with $2 \mathrm{ml}$ tris-acetate buffer or $2 \mathrm{ml}$ CLP solution. 
Occasionally, the mixtures were gently shaken and the speed and quality of coagulation were observed at $21^{\circ} \mathrm{C}$ and $\mathrm{pH} 7 \cdot 5$.

In order to see the effect of CLP and clostridial collagenase on the vesiculasemediated coagulation of the seminal vesicle secretion, the following experiment was performed: $0 \cdot 2-\mathrm{ml}$ portions of the seminal vesicle secretion were incubated

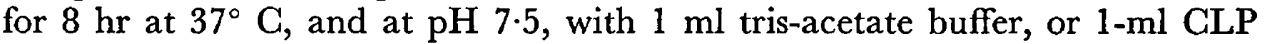
solution, or $1-\mathrm{ml}$ clostridial collagenase solution $(30 \mu \mathrm{g} / \mathrm{ml})$, respectively. At the beginning and end of incubation, two 40- $\mu$ l samples were taken from each incubation mixture for electrophoretic examination of the cathode- and anode-migrating proteins.

After an 8-hr incubation, each incubation mixture was cooled to $21^{\circ} \mathrm{C}$ and transferred to a Petri dish containing a $1-\mathrm{ml}$ vesiculase solution. The speed and quality of coagulation were observed.

Clostridial collagenase and CLP activities were determined using PZpentapeptide as substrate, as described previously (Koren \& Milković, 1973). The effects of some inhibitors (DFP, EDTA, Trasylol and cysteine) on GLP activity were examined following preincubation of each inhibitor with CLP for $30 \mathrm{~min}$.

Proteolytic activity was determined according to the method of Kunitz (1947) using $1 \%$ casein, $1 \%$ haemoglobin and $1 \%$ albumin as substrate, and was expressed in tryptic units. The concentration of soluble protein was determined by the ultraviolet absorption method described by Waddell (1956). Amidase activity was measured by the method of Erlanger, Kokowsky \& Cohen (1961). For disc electrophoresis on polyacrylamide gels, the method of Reisfeld, Lewis \& Williams (1962) at $\mathrm{pH} 8.3$ and $5.5 \%$ acrylamide concentration was used. The gels were stained with $1 \%$ amido black and differentiated in $7 \%$ acetic acid.

\section{RESULTS}

The CLP obtained from rat testis homogenate was purified by repeated (about 27 times) acetone precipitation and gel filtration. Its specific activity was 2.97 in the homogenate and 76.34 after gel filtration (Table 1). The specific activity of clostridial collagenase A was 4600 units/mg protein. At $\mathrm{pH} \mathrm{7.5,} \mathrm{CLP}$ showed no measurable proteolytic activity (Table 1), and no amidase activity.

Table 1. Proteolytic and CLP activity in rat testis homogenate and in purified CLP

\begin{tabular}{l|c|c|c|c}
\hline & \begin{tabular}{c}
$\mid c$ \\
Specific \\
\cline { 3 - 4 } $\begin{array}{c}\text { CLP activity } \\
\text { (units/mg protein) }\end{array}$
\end{tabular} & $\begin{array}{c}\text { Substrate } \\
\text { casein } \\
\text { (units/mg protein) }\end{array}$ & $\begin{array}{c}\text { Substrate } \\
\text { albumin } \\
\text { (units/mg protein) }\end{array}$ & $\begin{array}{c}\text { Substrate } \\
\text { haemoglobin } \\
\text { (units/mg protein) }\end{array}$ \\
\hline $\begin{array}{l}\text { Rat testis } \\
\text { homogenate }\end{array}$ & 2.97 & 0.75 & 1.1 & 0.67 \\
Purified GLP & 76.34 & $<0.05$ & $<0.05$ & $<0.05$ \\
\hline
\end{tabular}

CLP = collagenase-like peptidase, 
Table 2. Activity of the purified rat testis CLP in the presence of various inhibitors

\begin{tabular}{l|c|c}
\hline Inhibitor & $\begin{array}{c}\text { Concentration of inhibitors } \\
\text { in the reaction mixture } \\
\text { during the determination } \\
\text { of the activity }\end{array}$ & $\begin{array}{c}\text { Total } \\
\text { CLP activity } \\
\text { (units/ml) }\end{array}$ \\
\hline DFP & & $36 \cdot 00$ \\
Trasylol & $5.7 \mathrm{mM}$ & $35 \cdot 40$ \\
& $11 \mathrm{mM}$ & 38.00 \\
EDTA & $500 \mathrm{units} / \mathrm{ml}$ & $36 \cdot 60$ \\
& $1250 \mathrm{units} / \mathrm{ml}$ & 37.00 \\
Cysteine & $6.0 \mathrm{mM}$ & 17.28 \\
& $12 \mathrm{mM}$ & 0.24 \\
& $20 \mathrm{mM}$ & 14.40 \\
\hline
\end{tabular}

For abbreviations see text.

The activity of CLP was inhibited by EDTA and cysteine but not by DFP and Trasylol (Table 2).

\section{Coagulation of the vesicular secretion}

About $20 \mathrm{~min}$ after adding $0.2 \mathrm{ml}$ vesicular secretion to $2 \mathrm{ml}$ tris-acetate buffer, numerous rough coagula were formed as a result of spontaneous coagulation. By contrast, $60 \mathrm{~min}$ after adding vesicular secretion to $2 \mathrm{ml} \mathrm{CLP}$, only thin fluffy coagula were found. We also noted that spontaneous coagulation of the

\section{EXPLANATION OF PLATE 1}

Fic. 1. Disc electropherograms of the cathode-migrating proteins from the reaction mixtures composed of:

A. $0.2 \mathrm{ml}$ rat vesicular secretion and $1 \mathrm{ml}$ tris-acetate buffer, at the beginning of incubation.

B. $0.2 \mathrm{ml}$ rat vesicular secretion and $1 \mathrm{ml}$ vesiculase solution after an $8 . \mathrm{hr}$ incubation at $37^{\circ} \mathrm{C}, \mathrm{pH} 7.5$.

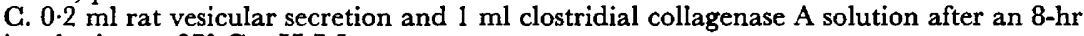
incubation at $37^{\circ} \mathrm{C}, \mathrm{pH} 7 \cdot 5$.

D. $0.2 \mathrm{ml}$ rat vesicular secretion and $1 \mathrm{ml} \mathrm{CLP}$ solution after an $8-\mathrm{hr}$ incubation at $37^{\circ} \mathrm{C}$, pH 7.5 .

E. $0.2 \mathrm{ml}$ rat vesicular secretion and $1 \mathrm{ml}$ tris-acetate buffer after an 8-hr incubation at $37^{\circ} \mathrm{C}, \mathrm{pH} 7.5$.

$\mathrm{S}$-start. The arrows point to the basic protein degradation products.

Fig. 2. Disc electropherograms of the anode-migrating proteins from the reaction mixtures composed of:

A. $0.2 \mathrm{ml}$ rat vesicular secretion and $1 \mathrm{ml}$ tris-acetate buffer at zero time.

B. $0.2 \mathrm{ml}$ rat vesicular secretion and $1 \mathrm{ml}$ vesiculase solution after an $8 \mathrm{hr}$ incubation at $37^{\circ} \mathrm{C}, \mathrm{pH} 7 \cdot 5$.

C. $0.2 \mathrm{ml}$ rat vesicular secretion and $1 \mathrm{ml}$ clostridial collagenase A solution after an $8-\mathrm{hr}$ incubation at $37^{\circ} \mathrm{C}, \mathrm{pH} 7 \cdot 5$.

D. $0.2 \mathrm{ml}$ rat vesicular secretion and $1 \mathrm{ml} \mathrm{CLP}$ solution after an $8-\mathrm{hr}$ incubation at $37^{\circ} \mathrm{C}$, $\mathrm{pH} 7.5$.

E. GLP solution alone.

F. $0.2 \mathrm{ml}$ rat vesicular secretion and $1 \mathrm{ml}$ tris-acetate buffer after an $8-\mathrm{hr}$ incubation at $37^{\circ} \mathrm{C}, \mathrm{pH} 7 \cdot 5$.

$\mathrm{S}-$ start. The arrows point to the new protein bands. 
PLATE 1

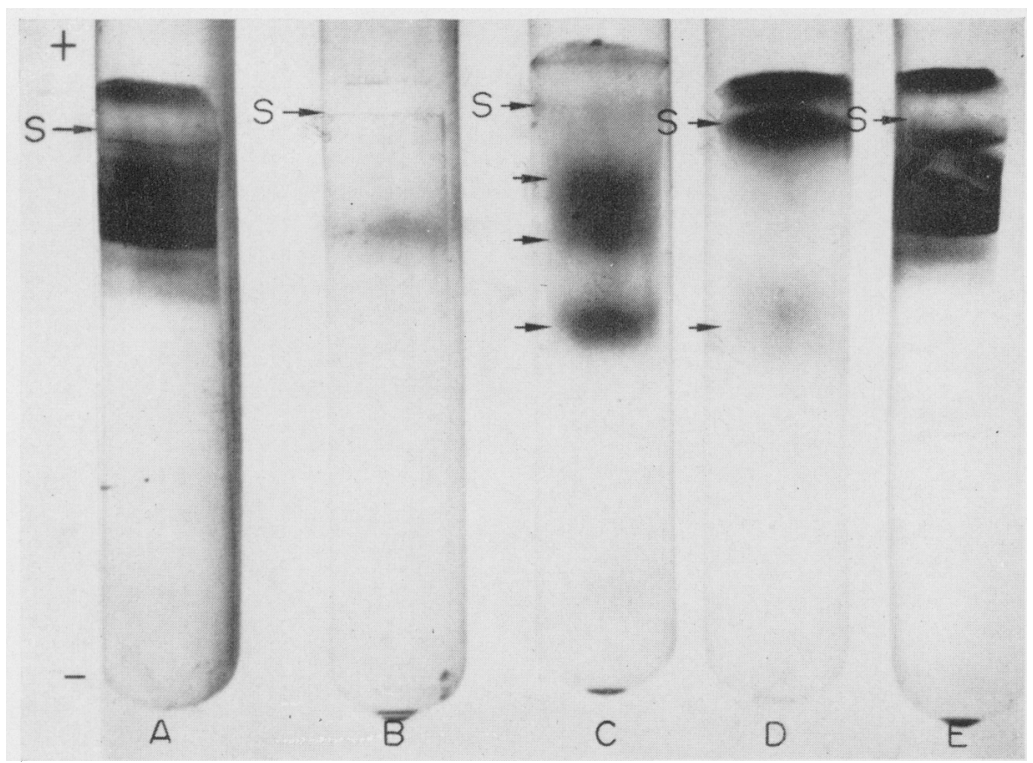

FiG. I

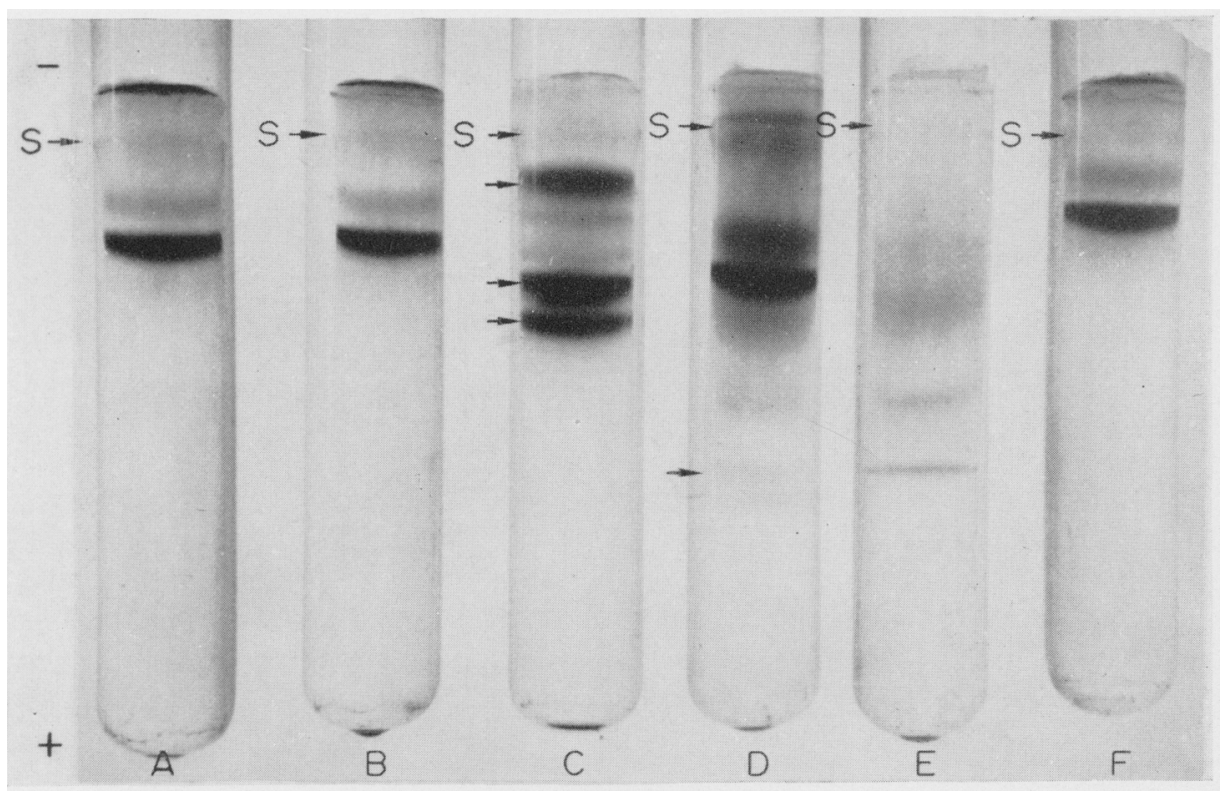

FIG. 2

(Facing p. 164) 
rat vesicular secretion in vitro depended upon temperature. At $37^{\circ} \mathrm{C}$ and $\mathrm{pH} 7.5$, vesicular secretion diluted in tris-acetate buffer did not coagulate even within $8 \mathrm{hr}$ while at $5^{\circ} \mathrm{C}$ coagulation occurred within $5 \mathrm{~min}$.

When, after an 8-hr incubation at $37^{\circ} \mathrm{C}, \mathrm{pH} \mathrm{7.5}$, the incubation mixtures were added to vesiculase solution, three different types of coagulation were obtained: the tris-acetate buffer-vesicular secretion mixture resulted, within $25 \mathrm{sec}$, in a compact massive coagulum sticking to the bottom; the CLPvesicular secretion mixture gave, within $4 \mathrm{~min}$, small particles suspended in the solution; the addition of the clostridial collagenase-vesicular secretion incubation mixture to vesiculase solution resulted in very fine and small particles within $9 \mathrm{~min}$. No further macroscopic changes were noted in any of these mixtures even after standing for $12 \mathrm{hr}$ at $21^{\circ} \mathrm{C}$.

\section{Electrophoretic study of the effects of CLP and clostridial collagenase on the proteins from seminal vesicle secretion}

The disc electropherograms of the soluble fractions of incubation mixtures taken at zero time and/or before they were tested for coagulability in vesiculase solution are shown in Plate 1. By this method, four cathode-migrating protein bands could be demonstrated in the vesicular secretion (Pl. 1, Fig. 1, A and E). Vesiculase solution, clostridial collagenase solution and CLP solution, alone, did not contain demonstrable cathode-migrating proteins. Incubation of the vesicular secretion in tris-acetate buffer alone did not affect the cathodemigrating proteins (Pl. 1, Fig. 1, E), while incubation of the vesicular secretion with vesiculase solution resulted in almost complete disappearance of these proteins (P1. 1, Fig. 1, B). Incubation of the vesicular secretion with clostridial collagenase resulted in three demonstrable degradation products (Pl. 1, Fig. 1, $\mathrm{C}$, arrows), while incubation with CLP alone resulted in one whose electrophoretic mobility was identical to that of the fastest clostridial collagenase degradation product (Pl. 1, Fig. 1, D, arrow). Three anode-migrating protein bands were demonstrated in vesicular secretion (Pl. 1, Fig. 2, A), which remained unchanged following incubation of the vesicular secretion in trisacetate buffer (Pl. 1, Fig. 2, F) or in vesiculase solution (Pl. 1, Fig. 2, B). Incubation of the vesicular secretion in clostridial collagenase A resulted in their disappearance and the appearance of three new intensive protein bands with different electrophoretic mobility (Pl. 1, Fig. 2, G, arrows). Following incubation of vesicular secretion in purified CLP solution, only a very discrete protein band appeared near the front (Pl. 1, Fig. 2, D, arrow). At the concentrations used in our experiments, vesiculase and clostridial collagenase solutions did not contain demonstrable anode-migrating proteins, while CLP solution showed four anode-migrating protein bands (Pl. 1, Fig. 2, E). The effect of CLP on vesicular secretion proteins could be inhibited by cysteine (50 mm) but not by Trasylol (625 units/ml incubation mixture).

\section{DISGUSSION}

Our results constitute evidence that CLP from rat testis and clostridial collagenase $\mathrm{A}$ are capable in vitro of modifying to a significant extent the coagulation 
process of the rat seminal vesicle secretion. This applies to spontaneous (Manyai, 1964) and vesiculase-mediated coagulation.

Disc electrophoresis of soluble proteins in seminal vesicle secretion at $\mathrm{pH} 8.3$ has shown that CLP and clostridial collagenase exert a lytic effect on basic proteins. It has also demonstrated that clostridial collagenase has a lytic effect on neutral and acidic proteins. The only explanation for the appearance of new intensive anode-migrating protein bands after the incubation of vesicular secretion with clostridial collagenase (Pl. 1, Fig. 2, G) seems to be that some degradation products of the basic protein have no basic character and are anode-migrating at $\mathrm{pH} 8.3$.

Vesiculase does not affect the neutral and acidic proteins, but acts upon the basic proteins causing their disappearance from the soluble fraction of vesicular secretion. Little is known about the mechanism of the vesiculase action. Notides \& Williams-Ashman (1967) believe in the possibility that vesiculase elicits the precipitation of basic proteins by their transamination. Whatever the mechanism by which vesiculase causes coagulation of the vesicular secretion, it is clear that basic proteins must be intact for the formation of a coagulum similar to the copulatory plug. As CLP is also present in spermatozoa (Koren \& Milković, 1973), it is possible that this enzyme, by its lytic action, promotes the release of spermatozoa from the copulatory plug.

We reported previously (Koren \& Milković, 1973) that the substrate specificity (cleavage site in PZ-pentapeptide) was the same for clostridial collagenase and CLP. The results presented here point to further similarities. The failure of DFP to inhibit CLP excludes this enzyme from the group of serine proteases. Cysteine and EDTA inhibit CLP, which excludes CLP from the group of cysteine proteases. Inhibition by EDTA indicates that CLP could be a metalloenzyme, like clostridial collagenase which contains $\mathrm{Zn}$ in the active site (Seifter \& Harper, 1970). Trasylol which does not inhibit clostridial collagenase does not inhibit CLP either. A certain similarity in the effect of both enzymes on the seminal vesicle basic proteins also exists.

In the light of recent data pointing to the broader specificity of clostridial collagenase A (Soberano \& Schoellmann, 1972), it is interesting to note that the basic protein from the rat seminal vesicle does not contain proline or hydroxyproline, amino acids considered to be essential for collagenase specificity, and does not resemble collagen (Manyai et al., 1965; Notides \& WilliamsAshman, 1967).

\section{ACKNOWLEDGMENTS}

This work was supported in part by research grant No. 720-0440 from the Ford Foundation, New York, and grant No. IV/3 from the Croatian Republican Research Fund.

\section{REFERENGES}

ERLANGer, B. F., Kokowsky, N. \& CoHen, W. (1961) Preparation and properties of two new chromogenic substrates of trypsin. Archs Biochem. Biophys. 95, 271.

Gotterer, G., Ginsberc, D., Schulman, T., Banks, J. \& Williams-Ashman, H. G. (1955) Enzymatic coagulation of semen. Nature, Lond. 176, 1209.

HART, R. G. (1968) The mechanism of action of Cowper's secretion in coagulating rat semen. $\mathcal{F}$. Reprod. Fert. 17, 223. 
HarT, R. G. (1969) The effect of coagulating gland secretion on the coagulating activity of Cowper's secretion in the rat. Biol. Reprod. 1, 197.

HART, R. G. (1970) Cowper's gland secretion in rat semen coagulation. Biol. Reprod. 3, 347.

Koren, E. \& Mrlković, S. (1973) Collagenase-like peptidase in human, rat and bull spermatozoa. 7 . Reprod. Fert. 32, 349.

Kunitz, M. (1947) Grystalline soybean trypsin inhibitor. II. General properties. F. gen. Physiol. 30, 291.

MANN, T. (1954) The two components of semen, spermatozoa and seminal plasma. In: The Biochemistry of Semen, p. 1. Eds. Sir Rudolph Peters and F. G. Young. Methuen, London.

MaNYaI, S. (1964) Isolation of the clottable protein from the secretion of the rat's seminal vesicle. Acta physiol. hung. 24, 419.

Manyai, S., Beney, L. \& Czuppon, A. (1965) Some characteristics of the clottable protein secreted by the seminal vesicles of the rat. Acta physiol. hung. 28, 105.

Notides, A. G. \& Williams-Ashman, H. G. (1967) The basic protein responsible for the clotting of guinea-pig semen. Proc. natn. Acad. Sci. U.S.A., 58, 1991.

Reisfeld, R. A., Lewis, V. J. \& Wildiams, D. E. (1962) Disc electrophoresis of basic proteins and peptides on polyacrylamide gels. Nature, Lond. 195, 281.

Seifter, S. \& HARPER, E. (1970) Collagenases. In: Methods in Enzymology, Vol. XIX, p. 613. Eds. S. P. Colowick and N. O. Kaplan. Academic Press, New York and London.

Soberano, M. E. \& Schoellmann, G. (1972) Specificity of bacterial collagenases: studies with peptides newly synthesized using the solid-phase method. Biochim. biophys. Acta, 271, 133.

WADDELL, W. J. (1956) A simple ultraviolet spectrophotometric method for the determination of protein. J. Lab. clin. Med. 48, 311. 